\title{
Scientific and educational leadership factors and the competitiveness of Ukraine
}

\author{
Larysa Gaievska \\ The National Academy of Public Administration, Office of the President of Ukraine \\ 20, Ezhena Pottier str., 03057, Kiev \\ Ukraine \\ e-mail: laurabest@ukr.net \\ Rayisa Naumenko \\ Faculty of Economics, Management and Psychology \\ Kyiv National Trade and Economic University \\ 19, Kyoto str., 02156, Kyiv \\ Ukraine \\ e-mail: naumenko_r@ukr.net \\ Iryna Fedulova \\ Faculty of Economics, Management and Psychology \\ Kyiv National Trade and Economic University \\ 19, Kyoto str., 02156, Kyiv \\ Ukraine \\ e-mail: felina9@ukr.net
}

\begin{abstract}
This paper is devoted to discussing the influence of leadership factors of higher education and science on the formation of a society that seeks to develop a competitive economy in Ukraine. One of the characteristic features of the modern world is the transformation of information and knowledge on the critical resource of economic development, which is evidence of the need to create favorable conditions for the development and implementation of innovative ideas and technologies.

The inclusion of scientific and educational components in the reproductive process of the activity of the smart society and its active participation in socioeconomic development with the focus on advanced production technologies requires in-depth study of innovative approaches to the quality of higher education and science. Taking into account the scientific and educational factors that influence the implementation of the principles of the formation of a competitive economy of Ukraine and the sustainable development of society, we perceive thee challenges as a significant problem for Ukraine at the present stage of creating a European educational space.
\end{abstract}

\section{Introduction}

Nowadays, in modern economic and social conditions, the inclusion of scientific and educational components in the reproductive process of the activity of the smart society and its active participation in socioeconomic development with the focus on advanced production technologies requires in-depth study of innovative approaches to the quality of higher education and science. The importance for the implementation and promotion of innovative activities becomes national innovative system developed innovation infrastructure and its degree of integration into the global network of information and technological flows. Pulses for uninterrupted and smooth functioning of the national innovation system are its high-quality educational and research components (Naushad 2018; or Radwan 2018). The quality of higher education and research is crucial for a society that tends to move towards a competitive economy with a focus on advanced manufacturing technologies and processes (Mishra and Singhania 2014). Today, economic globalization requires the preparation of highly educated workers who are able to perform complex tasks and adapt to a rapidly changing environment (Volchik et al. 2018). It is in higher education forming future developers of new progressive ideas and innovation, and also professionals who will develop and refine the technology in practice that contribute to the technological development of industries and the economy as a whole (Strielkowski 2018).

Therefore, an analysis of factors determining the quantitative and qualitative status of national education, as well as their dynamics is essential for understanding the driving forces in shaping the competitive economy of the country. That this is due to review the relevance of the problem.

Our paper is intended to justify the essence of the competitiveness of higher education, to identify the problems and promising directions of raising the level of competitiveness of the subjects of higher education and science 
on the formation of a society that seeks to develop a competitive economy in Ukraine of inclusion of scientific and educational components in the reproductive process of the activity of the smart society. During the research, the following scientific methods were used: analysis and synthesis (to identify the problems of ensuring competitiveness), theoretical search and abstract-logical (to characterize the essence and characteristics of competitiveness of higher education), structural and structural-functional analysis (for carrying out the strategic directions for the development of competitiveness of higher education and identify mechanisms for converting information and knowledge on critical resource of economic development and basic factors explain the significance of education and science to further improve the competitiveness of Ukraine's economy).

\section{Literature review}

Solving the problems of incorporating scientific and educational factors into the development of economic theories of reproduction and building a competitive economy and improving social and industrial relations in social and economic systems are devoted to the work of specialists in the field of education, science, and economics (Bogdanović et al. 2018).

Trends in economic and social developments in a globalized world economy shows gradual dominance of post-industrial society with characteristic changes in the structure of production and service resources and specifics of the labor force (Bell 2004; Čábelková et al. 2015; or Bordea et al. 2017). Despite deep enough processed the specific features of each of these areas build competitive national innovation system, in our view, require complex analysis in terms of causality, quantitative and qualitative characteristics of higher education and science in Ukraine, determine their dynamics and sources of formation. Whiddett and Hoolyforde (2000) distinguish the following competencies: business development (personal development, idea generation, and justifi cation); achievement results (planning, clarity in management decisions, goal setting); analysis (working with information); human resource management (teamwork, relationship management). An important task is the need for performance evaluation system of science and education in Ukraine compared with the best international standards. One of the objectives of the study is to evaluate the recent changes in the dynamics of events and indicators characterizing an educational component in the context of international competitiveness of these sectors and the economy as a whole (Stojanov et al. 2011). This is seen by the example of the economic laws of reproduction underlying social and economic development.

Porter (1990) showed how important is the link between the quality of higher education and the competitiveness of the state. Altbach (2016) considered contemporary problems and prospects for the development of higher education. Lane (2012) showing that universities are an important part of the country's economic development. Lopez-Leyva and Rhoades (2016) viewed the performance of global competitiveness and higher education competitiveness between two groups of countries. Bagmet and Liakhovets (2017) viewed the analysis of study results concerning the attitude of the population of Southern Ukraine to the European Union and willingness to implement the European education standards at higher education institution. Dul'ová Spišáková et al. (2016) analysed and assessed the level of achievement of these two sub-objectives in the Member States in 2014, with the emphasis on the southern countries of the European Union as well as to estimate the the degree of fulfillment, respectively failure of the target values until the year 2020. Androniceanu and Ohanyan (2016) reviewed approaches to monitoring the quality assessment of higher education. Kupets (2015) emphasized the hybrid inefficient version of education with the old Soviet traditions of centralized management and inadequately implemented European standards autonomous management and the principles of the Bologna process. Many works of these authors also investigated the matter and the formation of high-quality education system, assessed the status and trends of the scientific part of the national innovation system. Problems of education that would meet the highest international standards (Strielkowski 2017). These problems require further research that influenced the formation and purpose of the study shows its timeliness and relevance. Inclusion of scientific and educational components in the reproduction process activity smart society and its active participation in the socio-economic development with a focus on advanced production technology requires in-depth study of scientific approaches to the analysis of the quality of higher education and science.

\section{Results and outcomes}

One can see that higher education in Ukraine has always occupied a special place among the living standards of people in planning their future. If you look at the evolution of higher education in Ukraine, we can isolate certain periods of its formation. Thus, in early 1990s, independent Ukraine received the highly educated population with a dominating respect to education as one of the basic values. Even if the small funding for education over the next decade the proportion of the population with higher education increased. At this time, begins to fight for survival public universities, private universities there. Universities become "forge" diplomas low quality of the 
students' knowledge and high corruption. Since the 2000s began reforming higher education in order to improve its quality. Thus, in 2005. starts approaching the evaluation system in universities to European standards and the Bologna Process. But the result was an inefficient hybrid version of the old Soviet educational tradition of centralized management and adequately implemented European standards and principles of autonomous management of the Bologna process (Kupets 2015). The current state of higher education in Ukraine, on the one hand, the dynamics can be described through the annual number of entrants and universities (Table 1).

Table 1. Dynamics of universities and students in Ukraine in 2010-2016

\begin{tabular}{|l|c|c|c|c|c|c|}
\hline \multicolumn{1}{|c|}{ Indicator } & $2010 / 2011$ & $2011 / 2012$ & $2012 / 2013$ & $2013 / 2014$ & $2014 / 2015$ & $2015 / 2016$ \\
\hline $\begin{array}{l}\text { The number of student in } \\
\text { higher education I - IV } \\
\text { accreditation, thsd. }\end{array}$ & 2418.1 & 2246.4 & 2106.2 & 1992.9 & 1689.2 & $1,605.27$ \\
\hline $\begin{array}{l}\text { Number of universities I IV } \\
\text { accreditation, ed. }\end{array}$ & 813 & 805 & 785 & 767 & 664 & 659 \\
\hline $\begin{array}{l}\text { The average number of } \\
\text { students per one school, } \\
\text { people }\end{array}$ & 2974 & 2791 & 2683 & 2598 & 2544 & 2436 \\
\hline $\begin{array}{l}\text { The number of students per } \\
10,000 \text { population }\end{array}$ & 557 & 519 & 488 & 463 & 393 & 375 \\
\hline
\end{tabular}

Source: Own results

For so many university students and one university in Ukraine an average of 2.5 thousand. Students. In Poland, for example, in the 2013/2014 academic year, the number of students was about 1550 thousand. People who studied in 438 universities (Higher education institutions and their finances in 2013). It means that an average of one university accounted for 3.5 thousand students.

Dynamics of total institutions by ownership with respect to the years 2010/2011 showed that six years analyzed their total number decreased by $18.9 \%$, with marked reduction level equally inherent in both state and private universities. However, the number of private universities has decreased over this period by $23.1 \%$ and the government - by $17.6 \%$. If we compare the ratio of Universities by ownership, in Ukraine significantly dominated by the number of public universities. Thus, in 2016 their share was $72 \%$ (State Statistics Service of Ukraine 2018). In Poland, to compare public universities account for only $28 \%$ and in Georgia - about $24 \%$ (National Statistics Office of Georgia 2018).

The structure of the number of universities in Ukraine in terms of accreditation shown in Fig. 4. Level of accreditation shows the capacity of higher education institution to carry out a certain type of educational activities related to higher education and training. I-II levels of accreditation are university technical schools, colleges and other equivalent higher education. III-IV accreditation level institutions - it institutes, conservatories, academies and universities. In 2016 they were distributed, respectively, 56 to $44 \%$ with slight advantage in favor of the universities I-II levels of accreditation.

The share of students enrolled full-time studies and recent increases in 2016 is $71.1 \%$. In addition to evening and distance learning in Ukraine began development of distance learning. In the West, this form was already a long time and is very popular among students. The need for professional development or expansion of activities causes need quickly and efficiently learn new knowledge and skills, that's when the best form is distance learning.

Enrollment in Ukrainian universities gradually decreasing, reaching in 2015/2016, nearly 1,605.27 thousand students $33.6 \%$ less than in 2010/2011. Trend shows that the number of university students in six years annually decreased to 167.12 thousand students (State Statistics Service of Ukraine 2018). One of the reasons specified speakers are reducing the number of potential students due to demographic changes in Ukraine (Safonov 2010). The value of this indicator since 2006 has exceeded 100\%, ie the university more people entered than left school in the relevant year. This situation is explained by the fact that among incoming students also take into account part-time and evening forms of training, which often come Applicants who left school in previous years have or obtain second education. Some reduce the proportion of applicants seen in 2008 and 2009 when it was announced the passage of testing as a mandatory condition for admission to universities. Markedly reduced the number of applicants in 2011 , due to the fact that due to the passage of 11 to 12 -year secondary education in this year students had to finish school, another year continued their studies. According to the forecasts of the population of Ukraine starting from 2019 can be expected again increasing the number of entrants to higher education.

Among the sources of funding for training students in Ukraine is the main state budget and individuals. In the years 2015/2016 slightly dominated by the state budget, their share in total funding was $45.6 \%$, is 7.3 percentage points more than in 2010/2011, respectively (State Statistics Service of Ukraine 2018). 
Rapid economic growth primarily is due to the unique technical innovations that are necessary to maintain and develop. Modern production facilities requiring highly skilled professionals in STEM-education (Science, Technology, Engineering, and Mathematics), so there is a need in the teaching and learning of mathematics in the education system. In Ukraine, the share of STEM graduates in 2015 was $9.8 \%$, is higher than in Poland (6.8\%) and Hungary (6.3\%). In South Korea university programs of technical skills intensive statesponsored and engineering students get much more benefits (both financial and in terms of further opportunities of employment) than the humanities. Social Sciences and Humanities taught mainly at private universities.

Equally important in the formation of a competitive national innovation system gets creating conditions for effective development of scientific sphere countries. In our country the scientific field, as well as educational exhibit the same negative situation. And if progress can be seen, only on certain quantitative indicators. And not always increase quantitative assessment leads to higher quality. So, if increasing the number of graduate and doctoral students, the increasing number of institutions Postgraduate efficiency last remains very low. Thus, in 2016481 educational and research institutionand had graduate school, whose effectiveness by the number of protected theses for the last five years is about $25 \%$. The highest percentage of protected theses demonstrate medical sciences (62.4\%), military science (45.5\%) within 30-33\% - philological, geographical, legal, educational, political science, and physical education and sports. Among the lowest - agriculture (12.1\%) and veterinary (5.6\%) Science and Arts (9.8\%). Efficiency doctorate for 2010-2016 years. Ranges from 26 to $33 \%$. The largest proportion of protected theses also observed in health sciences $(63.6 \%)$, legal $(47.6 \%)$ and philological $(41.7 \%)$. The least effective - doctoral students in public administration (13.6\%) and physics and mathematics $(14.3 \%)$.

The trend in the annual percentage increase of applicants from potential applicants, on the one hand, looks like a positive trend, increasing the proportion of people with higher education. On the other hand, professional structure and the quality of education does not meet either international standards or demands from the domestic business, ie the potential labor market of graduates.

British company QS SAFE National System Strength conducted a research project entitled "Rating of the best system of higher education (Top 50)". This rating is an attempt through ratings and other indicators to assess not individual universities and all higher education system of the country as a whole. According to the rating of Ukraine in 2016 was at the $45^{\text {th }}$ place (RIA 2016).

About $82.5 \%$ of Ukrainian population has high school diplomas. Overall, Ukraine ranks $7^{\text {th }}$ in the world in terms of population with higher education. People with university diplomas we have more than of Denmark, New Zealand and Austria. Proof of failure to request such a number of specialists with higher education serve as the results of the study, according to which the average Ukrainian evaluate the quality of higher education $55.2 \%$ of respondents. Less than $15 \%$ of the population consider Ukrainian education to be oreally high quality, $58 \%$ of Ukrainians believe that a graduate degree makes it impossible to find a good job.

Among the respondents about the basic qualitative characteristics of higher education in Ukraine only $35.2 \%$ agree that the Ukrainian education provides good training, 36.4\% indicate that it can be realized talented and only $19.8 \%$ of respondents believe that education provides to find a good job

The issue of quality of higher education, more than ever, it is urgent. According to Art. 1 of the Law of Ukraine "On education" quality latter is defined as "a person acquired level of knowledge, skills and other competencies that reflect its competence in accordance with the standards of higher education". From the definition it is clear that the "responsibility" entrusted to the quality standards of higher education, which in Article 10 of this Law tlumachyatsya as a set of requirements for the content and results of educational activities higher education and research institutions, developed according to the National Qualifications Framework. These standards are formed according to claim 6 c. 13 of the Law, Scientific and methodical council with the National Agency for Quality Assurance in Higher Education and scientific-methodical commission, composed of representatives of the state, employers and their associations, institutions of all forms of ownership, scientific and other institutions. One of the principal conditions for improving the quality of education in that process of setting standards have to be a real connection qualification requirement of the modern business environment and control the formation of these competencies in university graduates. Such control can be carried out in the form of independent testing scientific and professional expertise to international standards. Stimulating to higher education quality function can perform independent monitoring research universities, as well as objective, independent ratings of Ukrainian universities. One of the principal conditions for improving the quality of education in that process of setting standards have to be a real connection qualification requirement of the modern business environment and control the formation of these competencies in university graduates. Such control can be carried out in the form of independent testing scientific and professional expertise to international standards. Stimulating to higher education quality function can perform independent monitoring research universities, as well as objective, independent ratings of Ukrainian universities. One of the principal conditions for improving the quality of education in that process of setting standards have to be a real connection qualification requirement of the modern business environment and control the formation of these competencies 
in university graduates. Such control can be carried out in the form of independent testing scientific and professional expertise to international standards. Stimulating to higher education quality function can perform independent monitoring research universities, as well as objective, independent ratings of Ukrainian universities. Such control can be carried out in the form of independent testing scientific and professional expertise to international standards. Stimulating to higher education quality function can perform independent monitoring research universities, as well as objective, independent ratings of Ukrainian universities. Such control can be carried out in the form of independent testing scientific and professional expertise to international standards. Stimulating to higher education quality function can perform independent monitoring research universities, as well as objective, independent ratings of Ukrainian universities.

In Ukraine, due to underfunding of science and bureaucratic obstacles decreases the number of applications for patents. First, the inventors of registered international patents abroad, based on the fact that it is easier to avoid going through all the stages of Ukrainian bureaucracy. Moreover, in this case the inventor receives a bonus of enhanced action of the geography of intellectual property rights in the invention. Thence, Ukraine over the past 20 years spent $20 \%$ of inventions. Second, the best minds Ukraine continue to migrate to developed countries - where their work is valued and paid more. Thence, registered patents are also missing.

Another indicator of trends in science dynamics proportion of expenditure on research and development (R\&D) in GDP, which shows a reduction in funding for 16 years at $40 \%$ In spite of the trend, it is unacceptably low rate of interest. Thus, in 2016 the R \& D was allocated $0.7 \%$ of GDP, while in developed countries is $3 \%$ reference point (eg, Germany and Finland $-2.9 \%$, China $-2.1 \%$ ), and some countries spend about $4 \%$ (Israel 4.3\%, South Korea - 4.2\%, Japan and Sweden - by 3.3\%) (World Atlas 2018).

Many countries have long changed the system of budgetary financing of science and put a large share of the costs on the shoulders of "non-budget sector" - private enterprises. The budget of a single country among the world's most powerful states and much less developed lion's share of research and innovation funded business. Moreover, countries with roughly the same budget allocation for research in comparison with Ukraine (at $0.7 \%$ of GDP) have significantly higher citation rates and the number of internationally recognized publications.

Examples of successful financing strategy research activities is Israel. Today the country spends $4.3 \%$ of total GDP on research and development and research - and this is the highest indicator among developed countries. Interesting is the fact that the state could afford to innovate spent only $0.5 \%$ - that is little more than a tenth of the total volume of GDP (about three times less than the average in developed countries). The remaining funds will invest in Israeli science and foreign business partners.

Table 2 shows that there is a correlation between the level of science funding as $\%$ of GDP and functions played by science in society. Apparently, if the country spending on science does not exceed 0.4 percent of GDP, its scientific potential can really realize only a social and cultural function. Increasing this parameter allows for the development of certain areas of research, the results of which have the chance to be marked by the world scientific community, ie to implement cognitive function of science. Only after crossing over the threshold value of this indicator the country has sufficient scientific potential, can count on a real transition to an economy of innovation type.

Table 2. The dependence of the functions of science in society, the level of funding

\begin{tabular}{|c|c|c|c|}
\hline $\begin{array}{c}\text { The level of funding for } \\
\text { science (\% of GDP) }\end{array}$ & less than $0.4 \%$ of GDP & less than $0.9 \%$ of GDP & more than $0.9 \%$ of GDP \\
\hline $\begin{array}{c}\text { The function of science in } \\
\text { society }\end{array}$ & sociocultural & cognitive & economic \\
\hline
\end{tabular}

Source: Malitsky et al. (2006)

Quite logical in today's realities of Ukrainian science is the fact that the performance of individual work catastrophically low, every scientist in Ukraine published 10 times fewer articles than the average in developed countries and it is given not only internationally recognized journals, but 60 professional Ukrainian media, the quality of which is highly questionable.

If we choose the basis for comparison of the leading world powers, Ukraine, with its situation in science is completely unattractive, each of the "Big Seven" (G7) published at least 20 times more scientific papers than Ukraine, the United States - nearly 100 times. Over the past 20 years the share of Ukrainian papers fell from $0.5 \%$ to almost $0.3 \%$ of the world total.

Another common criterion for evaluation of research activities have impact factor (from the English. "Impact" - effect) that is often used in international research practice. It displays overall citing articles in leading journals indexed all the same scientometric database Thomson Reuters Web of Science: the higher the number of links to the article, the more powerful and better scientific work of the researcher. For statistical comparison of various countries for their influential publications scientists commonly used weighted impact factor, averaged for all research. Global impact factor in all sectors is 1 . The result of stagnant Ukrainian science is very low 
impact factor, only $12 \%$ of all scientific works of domestic scientists come to the most advanced international magazines (the EU - 30\% in the US - 40\%) and is mainly articles published in collaboration with foreign partners. As a result, scientific works written by Ukrainian scientists in collaboration with Western scientists have much impact factor higher than one.

The absolute, most professors in Ukraine has zero impact factor of their research (do not cite their jobs, leading scientific centers were not invited, they did not act with plenary presentations at international scientific forums and are not members of the editorial boards of leading international publications).

The effectiveness of research and education component of the innovation infrastructure can also draw conclusions, based component of the Global Competitiveness Index of the country. For specific rating in 20172018 years. Ukraine ranked $81^{\text {st }}$ place out of 137 countries, which is four positions lower than in the previous rating introduce that in 2016-2017.

Table 3. The positions of Ukraine and some countries in the Global Competitiveness Index (GCI)

\begin{tabular}{|l|c|c|c|c|c|c|}
\hline Country & \multicolumn{7}{|c|}{ Years } \\
\cline { 2 - 7 } & $\begin{array}{c}2012-2013 \\
(144 \\
\text { countries })\end{array}$ & $\begin{array}{c}2013-2014 \\
(148 \\
\text { countries })\end{array}$ & $\begin{array}{c}2014-2015 \\
(140 \\
\text { countries })\end{array}$ & $\begin{array}{c}2015-2016 \\
(140 \\
\text { countries })\end{array}$ & $\begin{array}{c}2016-2017 \\
(138 \\
\text { countries })\end{array}$ & $\begin{array}{c}2017-2018 \\
(137 \\
\text { countries })\end{array}$ \\
\hline Ukraine & 73 & 84 & 76 & 79 & 85 & 81 \\
\hline Georgia & 77 & 72 & 69 & 66 & 59 & 67 \\
\hline Turkey & 43 & 44 & 45 & 51 & 55 & 53 \\
\hline Russia & 67 & 64 & 53 & 45 & 43 & 38 \\
\hline Poland & 41 & 42 & 43 & 41 & 36 & 39 \\
\hline
\end{tabular}

Source: World Economic Forum

Table 4 shows that follows the position of Ukraine on the Global Competitiveness Index for the last three years. Despite a slight improvement, this year we are still the worst position to assess the macroeconomic environment (121 seats), for the goods market efficiency (101 seats), the development of the financial market (120 seats), according institutions (96th), with compliance with the requirements of modern business (90 seats).

Table 4. Global Competitiveness Index and its components Ukraine

\begin{tabular}{|c|c|c|c|}
\hline \multirow[b]{2}{*}{ Composite index } & \multicolumn{3}{|c|}{ Place in the world } \\
\hline & $\begin{array}{c}2015-2016 \\
(140 \text { countries })\end{array}$ & $\begin{array}{c}2016-2017 \\
(138 \text { countries })\end{array}$ & $\begin{array}{c}2017-2018 \\
(137 \text { countries })\end{array}$ \\
\hline Basic requirements & 101 & 102 & 81 \\
\hline - Institutions & 130 & 102 & 96 \\
\hline - Infrastructure & 69 & 75 & 78 \\
\hline - Macroeconomic Environment & 134 & 128 & 121 \\
\hline - Health care and primary education & 45 & 54 & 53 \\
\hline performance Amplifiers & 65 & 74 & 70 \\
\hline - Higher education and training & 34 & 33 & 35 \\
\hline - Goods market efficiency & 106 & 108 & 101 \\
\hline - Labor market efficiency & 56 & 73 & 86 \\
\hline - Development of financial markets & 121 & 130 & 120 \\
\hline - Technological readiness & 86 & 85 & 81 \\
\hline - Market size & 45 & 47 & 47 \\
\hline Innovation and improvement factors & 72 & 73 & 77 \\
\hline $\begin{array}{l}\text { - Compliance with the requirements } \\
\text { of modern business }\end{array}$ & 91 & 98 & 90 \\
\hline - Innovation & 54 & 52 & 61 \\
\hline
\end{tabular}

Source: World Economic Forum (2018)

In general, Ukraine has improved its position by 7 of 12 . Most components lost (minus 13 points) component "Labor market efficiency." The trend towards deterioration has observed in studies last year, with those in last year, we downgraded him its position by 17 points. Also, Ukraine suffered losses estimated innovation component indices - ("minus" 9 points), infrastructure ("minus" 3 points) and a component that characterizes higher education and training ("minus" 2 points).

Negative factors for doing business in our country is defined (in descending order): inflation, corruption, political instability, high tax rates, the complexity of tax laws, government instability, difficult access to financing, inefficient government bureaucracy, regulation of the currency market, lack of education workers poor labor ethic, lack of ability to innovate, restrictive labor market regulations, inconsistent quality of infrastructure, crime and theft, poor quality health. 
Identify the major driving forces in education and science in shaping the competitiveness of Ukraine is possible, assessing the performance given in Table. 5. In the years 2017/2018 Ukraine improved its position compared to the previous year deposition for secondary education, the quality of management schools, the availability of specialized research and educational institutions and degree of training. The best value we have for admission to institutions of higher education (16th place), but it is a quantitative measure that does not reflect the quality of education. For other indicators Ukraine worsened its position. The most significant decline occurred in part of Internet access in schools - 9 positions.

Among the components of the evaluation of higher education and training compared to the previous year we have worsened their position on the quality of education ( $49^{\text {th }}$ place against $46^{\text {th }}$ in the previous year) and in terms of education $\left(16^{\text {th }}\right.$ place against $11^{\text {th }}$ in the previous year) and improved by a component of training in the workplace (68 place against 77 in the previous year). Overall, higher education and training Ukraine occupies $35^{\text {th }}$ place in the ranking and is two positions lower than last year, but five positions better than in 2014/2015, respectively.

Table 5. Global Competitiveness Index of Ukraine (2014-2018)

\begin{tabular}{|l|c|c|c|c|}
\hline $\begin{array}{l}\text { Components of the index related to } \\
\text { education and science }\end{array}$ & $\begin{array}{c}\mathbf{2 0 1 4 - 2 0 1 5} \\
\mathbf{( 1 4 0} \text { countries })\end{array}$ & $\begin{array}{c}\mathbf{2 0 1 5 - 2 0 1 6} \\
(\mathbf{1 4 0} \text { countries })\end{array}$ & $\begin{array}{c}\mathbf{2 0 1 6 - 2 0 1 7} \\
(\mathbf{1 3 8} \text { countries })\end{array}$ & $\begin{array}{c}\mathbf{2 0 1 7 - 2 0 1 8} \\
\text { (137 countries) }\end{array}$ \\
\hline Higher education and training & 40 & 34 & 33 & 35 \\
\hline The share of education & 14 & 14 & 11 & 16 \\
\hline - Enrollment in secondary education & 41 & 39 & 53 & 51 \\
\hline - Enrollment in higher education & 13 & 14 & 11 & 16 \\
\hline quality of education & 65 & 46 & 46 & 49 \\
\hline - Quality of education system & 72 & 54 & 56 & 56 \\
\hline - Quality and Mathematical Science study & 30 & 38 & 27 & 27 \\
\hline - Quality management schools & 88 & 87 & 93 & 88 \\
\hline - Internet access in schools & 67 & 44 & 35 & 44 \\
\hline Learning on the job & 88 & 74 & 85 & 79 \\
\hline $\begin{array}{l}\text { - The availability of specialized research } \\
\text { and educational institutions }\end{array}$ & 84 & 78 & 77 & 68 \\
\hline - The degree of training & 92 & 74 & 94 & 88 \\
\hline
\end{tabular}

Source: World Economic Forum (2018)

The approval of high-tech industries Development Strategy by 2025 and approved plan for its implementation examined the relationship that exists between an index of human capital and GDP per capita. As one can see the relationship between these parameters is quite dense, indicating that education serves as a basis for the creation of wealth and the right development strategy-based education and training can provide the country's well-being and sustainable development. Research and education are critical factors in the development of any society, will provide formation and development of national innovation system of the country especially in the context of the fourth industrial revolution, as is the development of new technology platforms that bring together supply and demand and break the existing economic structure.

Today there is a sharp increase in demand for skilled workers and reduce the need for workers with low skills. In the near future, to be qualified in the labor market, one must be able to adapt to changing situations and to develop their skills in accordance with progress in this crucial role will be played by education and research.

\section{Conclusions}

Overall, we can conclude that building a competitive economy in Ukraine in current conditions depends on the efficient functioning within a single system, each component of the national innovation system. The unsatisfactory state of Higher Education and Science of Ukraine, in our opinion, is the result of a historical evolution of the existing and inefficient state regulation in this sphere. Among the prevailing trends in higher education can mention the reduction of entrants to higher education resulting from demographic fluctuations, insufficient quality of education received by university graduates in the background unreasonably large number of educational institutions.

Higher education in Ukraine since independence held certain periods in its formation, during which determined its specific social and economic processes in the country. So, the education system has gone from fundamental standards through uncontrolled financial self-sufficiency to the modern hybrid version of ineffective education from the old Soviet tradition of centralized management and some standards implemented European educational space.

Unsatisfactory state of scientific areas associated with both unrealized and often lost, potential domestic science, with low funding this area, which is 4 times is less than in developed countries. Therefore, it is more 
appropriate to concentrate efforts on analyzing the causes and factors of the quality of the scientific and educational sphere in Ukraine in order to achieve its positive dynamics. Is inefficient and its functioning, as evidenced by the low level of productivity postgraduate and doctoral when on average only every fourth research comes to fruition. Low is also the level of innovation and the technologies and processes in the industry.

However, problems in the system of Ukrainian science and education, lack of Ukrainian universities in the Top-100 best Institutions of higher education world and low international rankings components of the national innovation system, in our view, should not be seen as an excuse "debiting" of our higher education and research, as world leaders are like the "other weight" and therefore better concentrate on analyzing the causes and factors impact on the quality of scientific and educational sphere in Ukraine to achieve its positive dynamics.

The analysis of the characteristics of higher education and science of Ukraine and their dynamics makes it impossible to obtain detailed information on the totality of the factors influencing the current state and development prospects. These issues require further study on incentives and find ways to improve the quality of national education on the part of state bodies.

\section{References}

Altbach PG, Global perspectives on higher education, 1st edn. (Baltimore, MD: Johns Hopkins University Press, 2016), $352 \mathrm{p}$.

Androniceanu A, Ohanyan G (2016) Comparative approach on education and healthcare in Romania and Bulgaria as beneficiaries of the IMF financial assistance, Administratie si Management Public 26:25-48.

Bagmet M, Liakhovets O (2017) Towards the European Union's Education Standards: Expectations of the Ukrainians. Economics and Sociology 10(2):191-206. doi: 10.14254/2071-789X.2017/10-2/14

Bell D, Hryaduschee postyndustryalnoe society. Experience of social prediction, 2nd edn. (Moscow: Academia, 2004), 788 p.

Bogdanović M, Vetráková M, Filip S (2018) Dark triad characteristics between economics \& business students in Croatia \& Slovakia: what can be expected from the future employees? Entrepreneurship and Sustainability Issues 5(4): 967-991. doi:10.9770/jesi.2018.5.4(19)

Bordea E, Manea M, Pelligrini A (2017) Unemployment and coping with stress, anxiety, and depression. Czech Journal of Social Sciences, Business and Economics 6(2):6-14. doi: 10.24984/cjssbe.2017.6.2.1

Č́belková I, Abrhám J, Strielkowski W (2015) Factors influencing job satisfaction in post-transition economies: the case of the Czech Republic. International Journal of Occupational Safety and Ergonomics 21(4):448-456. doi: 10.1080/10803548.2015.1073007

Dul'ová Spišáková, E, Gontkovičová B, Hajduová Z (2016) Education from the Perspective of the Europe 2020 Strategy: the Case of Southern Countries of the European Union, Economics and Sociology 9(2):266-278. doi: 10.14254/2071-789X.2016/9-2/18

Kupets O, Education in transition and job mismatch: Evidence from the skills survey in non-EU transition economies, 1st edn. (Kyoto Institute of Economic Research, Kyto, 2015), 56 p.

Lane JE, Higher education and economic competitiveness: Universities and colleges as economic drivers, $1^{\text {st }}$ edn. (New York: Suny Press, 2012), 237 p.

Law of Ukraine "On Higher Education" (2018) http://zakon4.rada.gov.ua/laws/show/1556-18. Accessed 27 Jul 2018

Lopez-Leyva S, Rhoades G (2016) Country competitiveness relationship with higher education indicators. Journal of Technology Management \& Innovation 11(4):47-55 doi: 10.4067/S0718-27242016000400007.

Malitsky BA, Bulkin IA, Popovic A, Shokun T (2006) Prospects of bringing science funding in accordance with the law and the needs of innovative economic development Science and Science 4: 29-40.

Mishra US, Singhania D (2014) Contrasting the Levels of Poverty against the Burden of Poverty: An Indian Case. International Economics Letters 3(2):26-35.doi: 10.24984/iel.2014.3.2.1

National Statistics Office of Georgia (2018) Statistics. http://www.geostat.ge. Accessed 29 Aug 2018 
Naushad M (2018) A study on the antecedents of entrepreneurial intentions among Saudi students. Entrepreneurship and Sustainability Issues 5(3):600-617. doi:10.9770/jesi.2018.5.3(14)

Porter ME (1990) The Competitive Advantage of Nations. Harvard Business Review 1(1):14-14.

Radwan, A (2018) Science and innovation policies in North African Countries: Exploring challenges and opportunities, Entrepreneurship and Sustainability Issues 6(1):268-282. doi: 10.9770/jesi.2018.6.1(17)

RIA (2016) Rating of countries with the best system of higher education. https://ria.ru/sn_edu/20160518/1432025012.html. Accessed 28 Aug 2018

Safonov VE (2010) Forecast aspects of higher education in the demographic crisis in Ukraine Scientific Bulletin of the Academy of municipal management. Series: Economy 8:122-129.

State Statistics Service of Ukraine (2018) Key indicators of higher education in Ukraine. http://www.ukrstat.gov.ua/. Accessed 29 Aug 2018

Stojanov R, Strielkowski W, Drbohlav D (2011) Labour migration and remittances: current trends in times of economic recession. Geografie 116(4):375-400

Strielkowski W (2018) A postdoc's purpose. Science 360(6384):27-27. doi: 10.1126/science.aat6008

Strielkowski W (2017) Will the rise of Sci-Hub pave the road for the subscription-based access to publishing databases? Information Development 33(5):540-542. doi: doi: 10.1177/0266666917728674

Volchik V, Klimenko 1, Posukhova O (2018) Socio-economic sustainable development and the precariat: a case study of three Russian cities. Entrepreneurship and Sustainability Issues 6(1):411-428. doi: 10.9770/jesi.2018.6.1(25)

Whiddett S, Hollyforde S, The Competency Handbook, 1st edn, (London: Institute of Personnel and Development, 2000), 160 p.

World Atlas (2018) Data. https://knoema.ru/atlas. Accessed 29 Aug 2018

World Economic Forum (2016) Competitiveness Rankings. http://reports.weforum.org/global-competitivenessreport-2015-2016/competitiveness-rankings/ Accessed 27 Jul 2018 